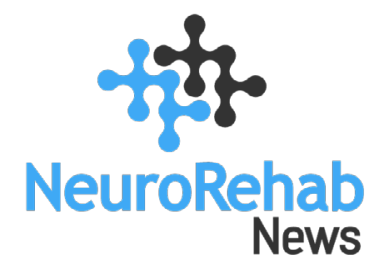

\title{
Imaginería Motora y Tratamiento del Dolor
}

Fisioterapia y Dolor

\section{Infografía}

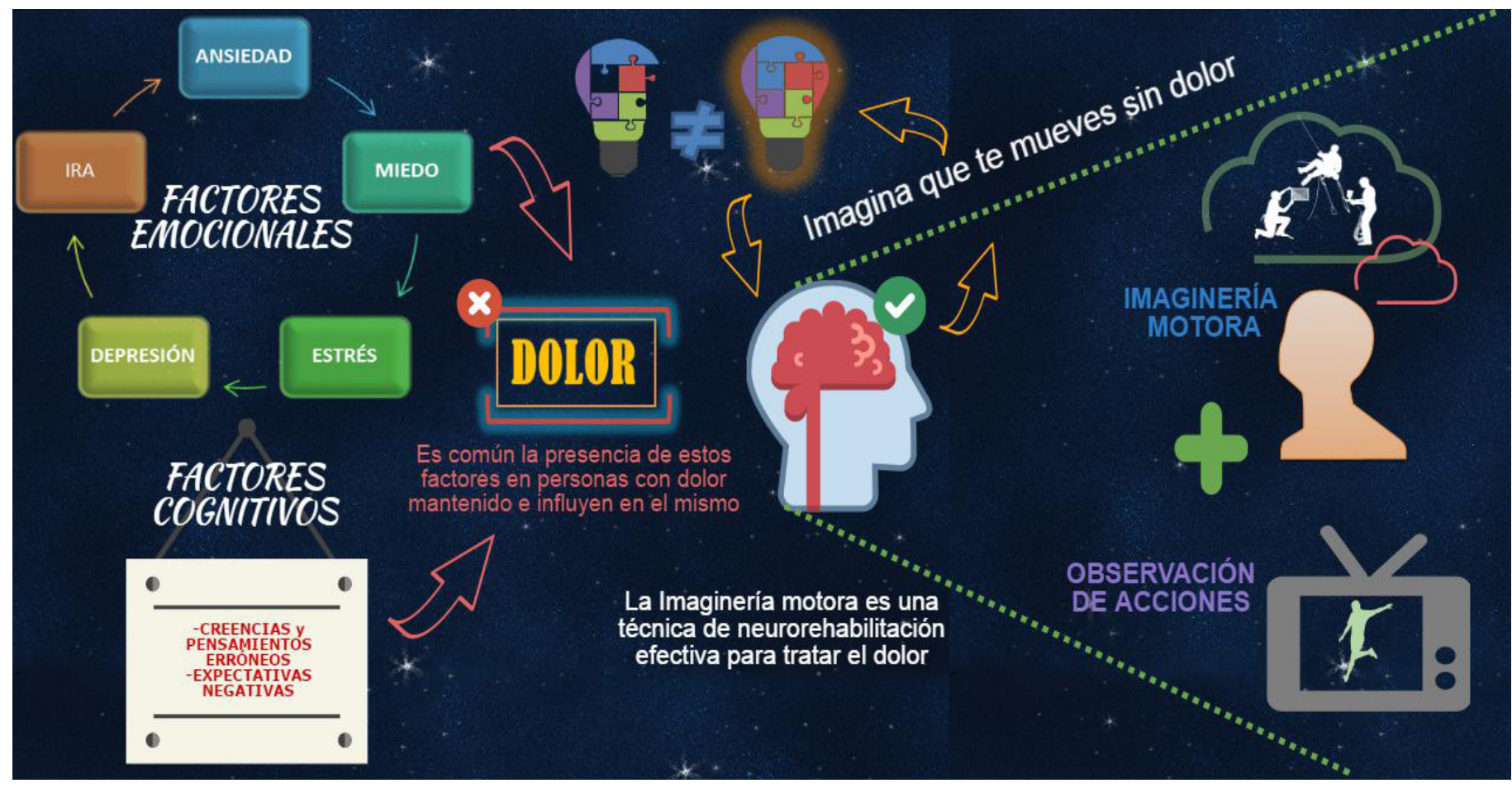

El dolor crónico se estructura como una memoria persistente donde factores afectivoemocionales como el miedo o cognitivos-conductuales como las creencias erróneas provocan una experiencia adversa que va a ser memorizada y, por tanto, son claves en la interpretación y percepción del dolor. Como herramienta de neurorehabilitación, la imaginería motora es una técnica empleada dentro del neuroentrenamiento sensoriomotor fundamentándose en el comportamiento del sistema nervioso como base del tratamiento. Mediante la observación de acciones y la imaginación de un movimiento sin dolor se consiguen cambios positivos en nuestro cerebro logrando una disminución tanto del dolor como de los factores asociados al mismo. 


\section{Sobre este artículo:}

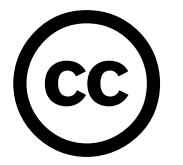

\section{Fuente /s:}

Coslett HB, Medina J, Kliot D, Burkey A. Mental motor imagery and chronic pain: the foot laterality task. J Int Neuropsychol Soc. 2010;16(4):603-12.

Fuente de la Imagen: imagen de NeuroRehabnews.com con fines unicamente ilustrativos.

Para citar este artículo: Cuenca-Martínez F. Imaginería Motora y Tratamiento del Dolor. NeuroRehab News 2016 dic; (1)1: e0007

Edición: Héctor Beltrán Alacreu y Roy La Touche

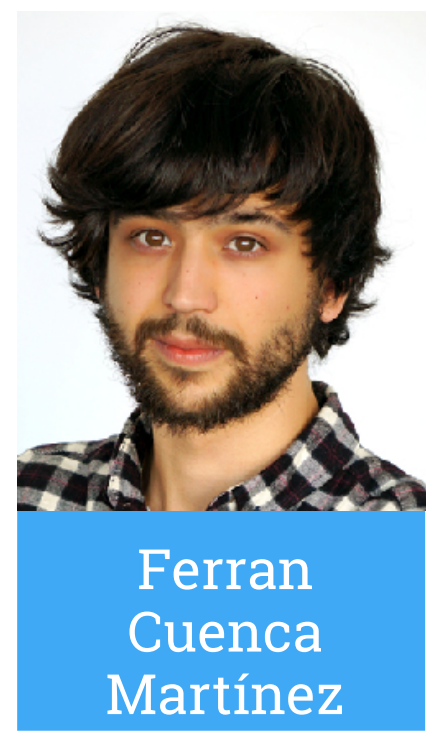

Ferran Cuenca Martínez 